University of Nebraska - Lincoln

DigitalCommons@University of Nebraska - Lincoln

Journal for the Advancement of Developing

Institute for the Advancement of Developing

Economies

Economies

2019

Determinants of Cost of Treating Water-Borne Diseases Among

Rural Households in South West Nigeria

Alaba M. Dare

Idris A. Ayinde

Adebayo M. Shittu

Sammy O. Sam-Wobo

Sakiru O. Akinbode

Follow this and additional works at: https://digitalcommons.unl.edu/jade

Part of the Econometrics Commons, Growth and Development Commons, International Economics Commons, Political Economy Commons, Public Economics Commons, and the Regional Economics

Commons

This Article is brought to you for free and open access by the Institute for the Advancement of Developing Economies at DigitalCommons@University of Nebraska - Lincoln. It has been accepted for inclusion in Journal for the Advancement of Developing Economies by an authorized administrator of DigitalCommons@University of Nebraska - Lincoln. 


\title{
Determinants of Cost of Treating Water-Borne Diseases Among Rural Households in South West Nigeria
}

\author{
Alaba M. Dare ${ }^{1 *}$, Idris A. Ayinde ${ }^{1}$, Adebayo M. Shittu ${ }^{1}$, Sammy O. Sam-Wobo ${ }^{2}$, Sakiru O. \\ Akinbode ${ }^{3}$ \\ ${ }^{1}$ Department of Agricultural Economics and Farm Management, Federal University of \\ Agriculture, Abeokuta, Ogun State, Nigeria. \\ ${ }^{2}$ Department of Pure and Applied Zoology, Federal University of Agriculture, Abeokuta, Ogun \\ State, Nigeria. \\ ${ }^{3}$ Department of Economics, Federal University of Agriculture, Abeokuta, Ogun State, Nigeria.
}

\begin{abstract}
This study determined the factors that influence the economic burden of water-borne diseases and the associated financial cost for rural households in southwestern Nigeria. A multi-stage random sampling method was used to select four hundred and thirty-seven rural households from whom data were collected for the study. Data were analyzed using descriptive statistics and cost of illness approach. The results revealed that an average household had six members with an average quarterly income of $\$ 80,717.52$ ( $\$ 160.00=1 U S$ dollar, at time of study). The sum of $\$ 28,571.36$ was incurred as economic cost of water-borne diseases per household per quarter in the study area. Gender $(p<0.05)$, access to safe water $(P<0.1)$, cholera epidemic $(p<0.01)$, diarrhoea infection $(p<0.1)$, access to improved toilet $(p<0.1)$ and State dummy $(p<0.01)$ were the significant factors affecting economic burden of water-borne diseases in the study area. The study therefore recommends that rural households should consume quality water or water from improved sources (borehole and well water) so as to combat water-borne diseases. They should also seek medical attention when they fall ill. In the same vein, the three tiers of government (federal, state and local) should give more priority to sensitizing rural households on water-borne diseases control programs in order to prevent economic losses resulting from loss of income and shortage of food supply.
\end{abstract}

Keywords: Cost of illness, diarrhoea, West Africa, Tobit model.

*Corresponding author: darealaba11@gmail.com/+234803 3690430

\section{INTRODUCTION}

Water is one of the most invaluable natural resources which is vital to human existence. The quality of drinking water is a powerful environmental determinant of health (WHO, 2011; Odhiambo, 2014). Consumption of quality water serves as a pillar for preventing water-borne diseases (WHO, 2011), thus, the provision of safe water is of great concern in most developing countries (Pritchard, Mkandawire, \& O'Neill, 2008). UN (2002) confirmed that with adequate supplies of safe drinking water, the incidence from some illnesses and death could drop by as much as $75 \%$. A major consequence of lack of safe drinking water is that a large proportion of persons had resorted to the use of potentially harmful sources of water. The implication of this is that people are exposed to cycles of innumerable diseases. 
WHO and UNICEF (2010) concluded that access to safe water and sanitation by rural households drastically reduced illness and mortality rate which might be caused by infectious agents, chemical pollutants and poor hygiene. The lack of safe water supply and sanitation facilities is, therefore, the main cause of outbreak of water-related and water-borne diseases like diarrhoea, malaria, cholera, typhoid fever and guinea worm, particularly in rural communities. Water contamination is caused by sewerage and industrial effluents, surface runoff and anthropogenic activities which alter the physical (e.g. colour, taste and smell) and chemical characteristics of water (Malik et al., 2012). As long as access to safe water and good sanitation practices in rural Africa is still low, particularly in Nigeria, the most populous country in Africa, the health and livelihood of families will be sternly affected (MacDonald, 2005). Water-borne pathogens are infecting 250 million people per year resulting in 10-20 million deaths (Dzwairo, 2006). Frequent water-borne diseases and illnesses had increased the cost of health care and poverty among rural households (Azizullah, Khattak, Ritcher, \& Harder, 2011).

Water-borne diseases contribute significantly to ill-health in the tropics. Improved health contributes to economic growth in various ways: it reduces production losses caused by workers' illness, it increases the enrolment of children in schools and makes them better in learning and it makes alternative use of resources that would otherwise have to be spent on treatment (World Bank, 1993). Some of the benefits derived from healthier workers are increased productivity, greater better paying job opportunities and longer working lives (Sauerborn, Adams, \& Hien, 1996). Health status is mostly used to explain wage rate, productivity, school performance, fertility and the demand for medical care (Rout \& Nayak, 2007). As will be applicable to this study, Sauerborn, Adams, and Hien (1996) differentiated financial cost of illness (direct cost) from time cost of illness (indirect cost). The financial cost includes expenditure on drugs, fees, transport to treatment site, lodging and food for accompanying household member(s). The time cost represents the sum of the opportunity costs of wages forgone by the sick individuals due to illnesses and opportunity cost of carers' time spent on treating or attending to the sick person or accompanying them for treatment (Sauerborn, Adams, \& Hien, 1996).

Since agriculture is the most important sector of Nigeria's economy engaging about $70 \%$ of the labour force (Omotesho, Adewumi, \& Ajayi, 1995; Manggoel et al., 2012), it is expected that agricultural sector would bear a significant fraction of the economic burden of water-borne diseases. The occurrence of these water-borne diseases (cholera, diarrhoea and dysentery) considered in this study might cause morbidity and devastating effects on labour which affects output, especially if illness coincides with the peak production period when labour demand is high. This study determined the factors that influence the economic burden of water-borne diseases among rural households in South West Nigeria as a case study and attempts were made to answer the following research questions:

i What is the time and financial cost incurred by rural households in the study area?

ii What factors influence the economic burden of water-borne diseases in the study area?

Findings from this study are expected to highlight the significance of water-borne diseases in terms of their effects on labour availability and farm income. Findings will be vital to policy making on health of rural households in Nigeria. Outcomes from this study could also be extended to other parts of developing countries in Africa and beyond that share similar rural settings to the study area. 


\section{METHODOLOGY}

\subsection{The Study Area}

The study was conducted in Ogun and Oyo States, Nigeria. Ogun State lies within latitude $6.9^{0} \mathrm{~N}$ and longitude $3.5^{\circ} \mathrm{E}$ and has its capital in Abeokuta. It is bordered by Lagos State to the south, Oyo and Osun States to the north, Ondo State to the east and the Republic of Benin to the west. The average daily temperature in Ogun State is $32^{\circ} \mathrm{C}$ with an annual rainfall of $2152 \mathrm{~mm}$. It has a land mass of $16,762 \mathrm{~km}^{2}$ and population density of $222 / \mathrm{km}^{2}$ (NOAA, 2015). The population of the Ogun State was estimated to be 3,920,208 in 2006 (NPC, 2006) and 4,791,670 in 2015, given an average annual growth rate of $2.47 \%$. The rainy season is usually between March and October, while the dry season occurs from November to February. The major rivers in Ogun State are Yewa and Ogun rivers. The River Ogun system has the River Ogun and River Ofiki starting in Oyo North and north-western part of Ogun Sate. River Ogun is joined by river Ofiki, to west of Igbo-Ora. The tributaries found in River Ogun are River Ogbara, River Opeki, River Ose, River Oso and River Awon which joins River Ogun at various locations north of Abeokuta. River Onigbongbo and River Ewekoro are the major tributaries south of Abeokuta. Crops grown in Ogun State are yam, rice, cassava, maize, cotton, palm oil, cocoa, timber, rubber and kola nut (Edia, 2018). The main language in Ogun State is Yoruba. It has 20 local government areas. It has two major government hospitals. Projection revealed that Ogun State is $45 \%$ urban and $55 \%$ rural (Adekoya, 2014).

Oyo State has its capital in Ibadan and approximately located between latitude $8.1^{0} \mathrm{~N}$ and longitude $3.4^{0} \mathrm{E}$. The average daily temperature in Oyo State is $25.9^{\circ} \mathrm{C}$ with an annual rainfall of $1190 \mathrm{~mm}$. It is bordered in the south by Ogun State and in the north by Kwara State, west by the Republic of Benin and in the east by Osun State. Oyo State has a land mass of 27,460 km², population density of $204 / \mathrm{km}^{2}$ and it is ranked 14th by size in Nigeria with the population of 5,591,589 (NPC, 2006). It was estimated at $6,834,599.23$ in 2015 given an average annual growth rate of $2.47 \%$ (World Bank, 2015). The principal rivers found in the Oyo State are Ogun, Oba, Oyan, Otin, Ofiki, Sasa, Oni, Erinle and Osun River. Agriculture is the main occupation of the people of Oyo State. The climate in the state favours the cultivation of crops such as maize, yam, cassava, millet, rice, plantain, cocoa tree, palm tree and cashew. The Yoruba people constitute the main ethnic group. It has 33 Local Government Areas (NPC, 2006). The predominant occupation of the ruralites is farming. Primary health care services exist in virtually all the Local Government Areas in Nigeria. Majority of the primary health care facilities in the rural areas were inadequate and malfunctioning in the study areas.

\subsection{Methods of Data Collection and Sampling Technique}

Data were collected with the aid of well- structured questionnaires which were administered to the selected households. The data for Ogun and Oyo States were administered between May to August 2013 and between September to December 2013, respectively. Data were collected on water-borne illness episodes, days lost to illness, cost of illness, treatment methods, coping strategies and daily wage rate. This study adopted a multi-stage sampling technique in both states using the Oyo and Ogun States Agricultural Development Program (ADP) zones. Each State had four ADP zones. 
The first stage featured the selection of all the four zones in Oyo State (which include Ibadan/Ibarapa, Saki, Ogbomoso and Oyo) and Ogun State (which include Abeokuta, Ikenne, Ilaro and Ijebu-Ode) using total enumeration techniques (all the zones were being sampled due to the peculiarity of water-borne diseases in the study areas). The selection was prompted by the prevalence of water-borne diseases in all the zones based on preliminary information from the ADP and Ministry of Health officials as well as the need to obtain adequate sample size for the study.

The second stage featured selection of blocks. Simple random and proportionate sampling techniques were used to select two (2) blocks per zone in both States. In the first instance, simple random sampling technique was used to select two (2) blocks in Ogun State. Proportionate sampling was then used to select more blocks in Oyo State on a ratio of 2:1 given its relative largeness. This was due to the fact that Oyo State had 33 blocks while Ogun State had 20 blocks. This gives a total of 16 blocks for Oyo State relative to eight 8 blocks in Ogun State.

In the third stage, proportionate sampling technique was also adopted on a ratio of 1:2 to select 14 cells in Ogun State and 28 cells in Oyo State. In the latter however, only 22 cells could be used for meaningful analysis due to general hostility (non-compliance and bias in divulging information) and perceived negative cultural belief (social norms) of the people for the study, as well as the nonresponsiveness of respondents in Oyo State.

In the fourth stage, systematic random sampling technique (having a rule of thumb for the number of respondents to be selected, for example, selecting every 3 households at regular interval) was adopted to pick fifteen (15) respondents per cell in each of the states. This gives a total of 210 respondents in Ogun State and 330 respondents in Oyo State. In Oyo State, 81.2\% of the questionnaire (268 respondents) could be used for meaningful analysis to achieve the objectives of the study. In the same vein, $80.5 \%$ of the questionnaire administered in Ogun State (169 respondents) could be used for meaningful analysis. Thus, the total sample size selected for Oyo (268 respondents) and Ogun (169 respondents) was 437 respondents.

\subsection{Analytical Techniques}

Descriptive statistics which involved the use of frequency, tables and percentages were used to describe the socio-economic characteristics of rural households. The Cost of Illness (COI) approach was calculated following Sauerborn, Adams, and Hien (1996) arithmetic indices procedure. The Tobit model was used to determine factors affecting the economic burden of disease.

\subsection{Direct and Indirect Cost of Water-Borne Diseases Incurred by Rural Households in the Study Area}

In analyzing economic burden of disease, a modified arithmetic index following Sauerborn, Adams, and Hien (1996), that is COI, was used to capture the direct and indirect cost of waterborne diseases aversion. The model specification which was adopted by Akinbode (2010) and Ibrahim, Okuneye, Dipeolu, and Ayinde (2010) was stated as follows: 
(a) Economic cost of water-borne diseases: This depicts the total financial cost, preventative cost and the total time cost with respect to disease exposure per episode

$\mathrm{E}=\sum(\mathrm{F}+\mathrm{P}+\mathrm{T})$

(Equation 1)

Where:

$\mathrm{E}=$ Economic costs of water-borne diseases in each household

$\mathrm{F}=$ Total Financial cost of health care in the last season ( $N$ ) signifying direct cost

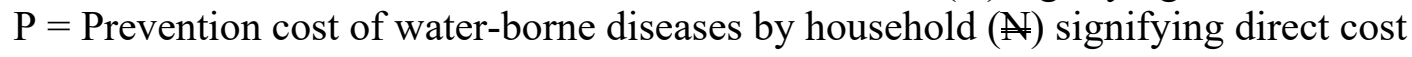

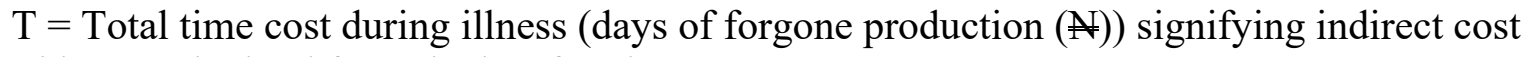

This was obtained from the last farming season.

(b) Direct cost of illness: This depicts cost of medication, fees, transport to treatment sites, lodging and food for accompanying household member per day with respect to disease episode (i.e. once in the last three months or in the last quarter). It is given as:

$\mathrm{F}=\mathrm{F}_{\mathrm{h}}+\mathrm{F}_{\mathrm{m}}+\mathrm{F}_{\mathrm{tr}}+\mathrm{F}_{\mathrm{s}}$

(Equation 2)

Where:

$\mathrm{F}=$ Total financial cost of treatment of water-borne diseases in the last season (N)

$\mathrm{F}_{\mathrm{h}}=$ Financial cost of herbs and other traditional treatment methods ( $N$ )

$\mathrm{F}_{\mathrm{m}}=$ Financial cost of medical consultancy $(\AA)$

$F_{\text {tr }}=$ Financial cost of medical travel ( $\left.~\right)$

$F_{\mathrm{s}}=$ Financial cost of subsistence i.e. Illness feeding cost ( $)$

(c) Prevention cost of water-borne diseases

$\mathrm{P}=\mathrm{P}_{\mathrm{wg}}+\mathrm{P}_{\mathrm{al}}+\mathrm{P}_{\mathrm{bg}}+\mathrm{P}_{\mathrm{st}}$

(Equation 3)

Where:

$\mathrm{P}=$ Prevention of water-borne diseases by rural households (

$\mathrm{P}_{\mathrm{wg}}=$ Cost of water guard ( $\left.\mathrm{N}\right)$

$\mathrm{P}_{\mathrm{al}}=$ Cost of alum (potassium aluminium sulphate $\left(\mathrm{KAl}\left(\mathrm{SO}_{4}\right)_{2}\right)(\mathbb{N})$

$\mathrm{P}_{\mathrm{bg}}=$ Cost of boiling ( $)$ : Inputted cost (cost of kerosene or fuelwood used in boiling) water.

$\mathrm{P}_{\mathrm{st}}=$ Cost of sanitation $(\mathrm{N})$

(d) Indirect cost of illness: This depicts income forgone during times of water-borne disease affliction:

$\mathrm{T}=\left(\mathrm{T}_{\mathrm{s}}^{*} \mathrm{as}^{*} \mathrm{w}\right)+\left(\mathrm{T}_{\mathrm{c}}^{*} \mathrm{ac} * \mathrm{w}\right)$

(Equation 4)

Where:

$\mathrm{T}=$ Opportunity cost of time due to days of work lost during sickness (days of forgone production)

$\mathrm{T}_{\mathrm{s}}=$ Time lost by the sick person (days of forgone production)

$\mathrm{T}_{\mathrm{c}}=$ Time lost by the caregiver(s) (days of forgone production) 
$\mathrm{a}=$ Productivity or age coefficient: According to World Bank (1993), Sauerborn, Adams, and Hien (1996), and Akinbode (2010); economic productivity of an individual rises from very early twenties (20s) to around age forty (40) and declines steadily afterwards. Arising from this, the productivity coefficient was classified according to the following categories:

Age $\leq 17$ years $=$ coefficient of 0.5

Ages between 18 and $40=$ coefficient of 1

Ages between 41 and $55=$ coefficient of 0.75

Ages between 56 and $65=$ coefficient of 0.67

Above 65 years of age $=$ coefficient of 0.5

$\mathrm{W}=$ daily wage rate $(\mathrm{N})$

$\mathrm{s}=$ related to the sick person/ individual

$\mathrm{c}=$ related to the caretaker(s)

$*=$ multiplication sign

The total financial cost of health, prevention cots and total time cost are aggregated as the economic cost of water-borne diseases.

\subsection{Tobit Model}

Tobit model was used to determine the factors affecting economic burden of water-borne diseases among rural households. The censored Tobit model was used due to the fact that available information was limited for some observations on the regressand. The regressand for Tobit model is usually a continuous variable. There is a dearth of information on past studies modelling Tobit for factors influencing the cost of treating water-borne diseases (EpiAnalysis, 2011).

The model is specified as follows:

$\mathrm{y}_{\mathrm{i}}=\mathrm{x}_{\mathrm{i}} \beta+\mu_{\mathrm{i}}$

(Equation 5)

Where:

$\mathrm{y}_{\mathrm{i}}=$ Total cost of illness $(\mathrm{N})$

$\mathrm{xi}=$ Explanatory variables

$\beta=$ Coefficients of the explanatory variables

$\mu \mathrm{i}=$ Error term

$y_{i}=\beta_{0}+\beta_{1} X_{1}+\beta_{2} X_{2}+\beta_{3} X_{3}+\beta_{4} X_{4}+\beta_{5} X_{5}+-------+\beta_{12} X_{12}+\varepsilon$

(Equation 6)

The explanatory variables are:

$\mathrm{X}_{1}=$ Age (years)

$\mathrm{X}_{2}=$ Gender (1- male, 0 otherwise)

$\mathrm{X}_{3}=$ Level of education (years)

$\mathrm{X}_{4}=$ Access to safe water ( 1 - access to safe water, 0 otherwise)

$\mathrm{X}_{5}=$ Incidence of cholera (1- cholera incidence, 0 otherwise)

$\mathrm{X}_{6}=$ Incidence of diarrhoea (1- diarrhoea incidence, 0 otherwise)

$\mathrm{X}_{7}=$ Incidence of dysentery (1-dysentery incidence, 0 otherwise)

$\mathrm{X}_{9}=$ Incidence of typhoid fever (1- typhoid fever incidence, 0 otherwise) 
$\mathrm{X}_{10}=$ Access to improved toilet (1-access to improved toilet, 0 otherwise)

$\mathrm{X}_{11}=$ Access to improved refuse dump site (1- access to improved refuse dump site, 0 otherwise)

$\mathrm{X}_{12}=$ State code (1- Ogun, 0 otherwise)

There was multi-collinearity between income, occupation (since majority of the households were farmers) and cost of illness. This forms the basis for age, gender and level of education being used as explanatory variables.

\section{RESULTS AND DISCUSSION}

\subsection{Socio-economic Characteristics of Respondents}

Table 1 shows the socio-economic characteristics of the respondents in the study areas. These include age, gender, marital status, level of education, occupation, household size and average monthly income of respondents.

Findings from the study areas revealed that $25.9 \%$ of the household heads fall within the age range of 41 to 50 years. The mean age of 48 years indicated that most of the respondents (household heads) were in their active age. This may have an implication on the level of water usage in terms of drinking if rural households were involved in drudgery activities (e.g. farming). In the study areas, $34.3 \%$ were female-headed households and $65.7 \%$ male-headed households. The result also showed that $90.6 \%$ of the respondents were married, $5.7 \%$ were singles, $3.4 \%$ were widows while $0.2 \%$ were divorced.

Table 1: Socio-economic Characteristics of Respondents

\begin{tabular}{lcc}
\hline Variables & Frequency & Percentage \\
\hline Age $^{\mathbf{1}}$ & & \\
$<20$ & 8 & 1.8 \\
$21-30$ & 60 & 13.7 \\
$31-40$ & 97 & 22.2 \\
$41-50$ & 113 & 25.9 \\
$51-60$ & 68 & 15.6 \\
$61-70$ & 67 & 15.3 \\
Mean $=48$ years & & \\
Total & 437 & 100 \\
Gender & & \\
Female & 150 & 34.3 \\
Male & 287 & 65.7 \\
Total & 437 & 100 \\
Marital Status & & \\
Married & 396 & 90.6 \\
Single & 25 & 5.7 \\
Divorced & 1 & 0.2
\end{tabular}


Widow(er)

Total

\section{Level of Education}

Primary

JSS

SSS

Tertiary

Standard 2

Informal

Total

Occupation

Farming

Civil servant

Artisans

Trading

None

Others

Total

Household size

$<4$

5-8

9-12

13-16

$17-20$

$>21$

Mean $=6$ people

Total

Income per month (N)

$<10,000$

$10,001-20,000$

20,001-30,000

$30,001-40,000$

$>50,001$

Mean income $=\$ 26,905.84$

Total

JSS = junior secondary school; SSS = senior secondary school; Tertiary refers to higher school of learning; Standard 2 refers to primary education; Informal means not educated.

Total number of observations $=437$; Total percentage $=100$
146

3.4

100

32

2.5

20.1

5

2.3

38

100

$256 \quad 58.6$

$\begin{array}{ll}10 & 2.3\end{array}$

$59-13.5$

$88 \quad 20.1$

$\begin{array}{ll}4 & 0.9\end{array}$

$20 \quad 4.6$

$437 \quad 100$

$142 \quad 32.5$

$\begin{array}{ll}215 & 49.2\end{array}$

$\begin{array}{ll}53 & 12.1\end{array}$

$\begin{array}{ll}19 & 4.3\end{array}$

$\begin{array}{ll}6 & 1.4\end{array}$

20.5

$437-100$

\begin{tabular}{l|l}
84 & 19.2
\end{tabular}

$108 \quad 24.7$

$25 \quad 5.7$

$50 \quad 11.4$

$437 \quad 100$ 
Approximately, $61.9 \%$ of the households had formal education while only $38.0 \%$ of the households had informal education. It is expected that formal education may enhance the respondents' understanding on the importance of using safe water and good sanitation practices in order to safeguard against various diseases most especially, water-borne diseases. The result further revealed that $58.6 \%$ of the respondents were farmers, while $20.1 \%$ and $13.5 \%$ were traders and artisans, respectively. Majority of the households (49.2\%) had between 5 and 8 people in their households and the mean household size was 6 . This is indicative of high level of family labor for the household's farm activities. Household members will render support and assistance in terms of farming activities, thereby increasing the household income. The modal monthly income in the study areas was less than $\$ 10,000$ (ten thousand naira) per month and this constituted $33.4 \%$, while the mean monthly income of respondents was $\$ 26,905.84$. However, respondents generally fell within the low-income household since an individual had an average income of $\$ 0.65$ per person per day. This had implication on their wellbeing and serves as a pivot for affordability of good quality water and sanitation practices.

\subsection{The Cost of Illness}

The Cost of Illness (COI) approach was used in this study to estimate the mean economic burden of water-borne diseases among rural farming households within the last three (3) months or the last quarter. COI provides the monetary estimate for the economic burden of disease. COI can be sub-divided into direct, indirect and tangible costs. However, intangible costs were not estimated due to the complexity and subjectivity of its estimation following Akinbode (2010). Intangible costs are most times excluded from COI estimation (Sauerborn, Adams, \& Hien, 1996).

The average total COI for the period (within the last three months or quarter) in the two states was \#28,571.36. This was calculated by summing up the total financial cost of health care in the last season, signifying direct cost; preventative cost of water-borne diseases by household, signifying direct cost; and the total time cost during illness (days of forgone production) signifying indirect cost in the last quarter of the farming season.

Table 2: Quarterly Average Total Cost of Illnesses Among Rural Households in Southwest Nigeria

\begin{tabular}{lcc}
\hline Cost & Amount (N) & Percentage \\
\hline Financial cost of drugs and herbs & $5,273.44$ & 18.4 \\
Financial cost of travel & 727.27 & 2.5 \\
Cost of subsistence (feeding) & $4,890.00$ & 17.1 \\
Time cost of sick person & $10,859.22$ & 38 \\
Time cost of caretaker & $5,846.20$ & 20.5 \\
Preventive cost & 975.23 & 3.4 \\
\hline Total Cost of Illness & $28,571.36$ & 100 \\
\hline
\end{tabular}

Exchange rate was $\$ 160$ to $\$ 1$ at time of study. 
From Table 2, $\$ 10,859.22$ (38\%) was spent on the time cost of the sick person. The total time cost stood at $\$ 16,703.40$ ( $\$ 104.40$ ) which is $58.5 \%$ of the total COI. Subsequently, $\$ 5,273.44$ (\$32.96) was spent on herbs and drugs. Only $3.4 \%$ of the total COI was spent on prevention. The implication of high cost incurred over time is the opportunity cost to farm production activities by the sick household member and the care giver. This has an adverse effect on farm output, labor productivity and farm income profit.

\subsection{Factors Affecting Economic Burden of Illness}

Tobit Regression (Table 3) was used to analyze factors affecting economic burden of illness. The result showed that gender, access to safe water, cholera epidemic, diarrhea infection, access to improved toilet and state dummy $(1=$ Ogun state, 0 otherwise) were significant. The model has a log likelihood of -3732.2346 , which depicts goodness of fit.

The coefficient of gender (male $=1$ ) was positively significant $(\mathrm{p}<0.05)$. This implies that male headed households have more likelihood to incur more cost on water-borne diseases. This is likely due to the lackadaisical attitude or nature of men with respect to their health. They might possess this erroneous belief of immunity against water-borne diseases.

The parameter estimate of access to safe water was negative and significant $(p<0.1)$. This shows that increase in access to safe water reduces cost of illness by $\$ 2,285.73$. This implies that access to safe water has the probability of reducing water-borne diseases significantly. Access to safe water will reduce the chances of exposure to water-borne diseases.

The coefficient of cholera epidemic had a positive relationship $(\mathrm{p}<0.01)$, indicating that increase in cholera epidemic will increase cost of illness by $\$ 8,033.70$. This implies that cholera as a waterborne disease imposes more cost on the farming household in the study areas. The higher the number of households with cholera epidemic, the higher the cost of illness and the lesser will be farm income.

Similarly, the coefficient of diarrhea infection was positive $(\mathrm{p}<0.1)$. This shows that increase in diarrhea infection has a likelihood of increasing cost of illness by $\$ 3,852.80$. This implies that diarrhea infection also imposes more cost on the farming household and could reduce farming activities and thus, income.

Access to improved toilet was negative and significant $(\mathrm{p}<0.1)$. This depicts that increase in access to improved toilet reduces the cost of illness by $\$ 5,537.59$. This shows that access to improved toilet has the likelihood of reducing water-borne diseases. Rural households that lacked access to improved toilet cannot curb the infestation of cholera epidemic, in which housefly served as the host.

The cost of illness is significantly related to State dummy (Ogun $=1)$ at $p<0.01$. This is so, given the fact that the frequency of occurrence of water-borne diseases was higher in Oyo relative to Ogun State and by implication, respondents from Oyo State are likely to incur more cost of $\$ 4,586.66$ (approximately $\$ 12.74$ ) for treatment of water-borne diseases. This is because Oyo state 
had almost twice the population of Ogun Study in this study. Consequently, Oyo State is relatively more rural in nature than its counterpart.

Table 3: Tobit Regression Estimation on Economic Burden of Illness

\begin{tabular}{lcr}
\hline Variable & Coefficient & t-value \\
\hline Age & -36.44 & -0.88 \\
Gender & $2814.32^{* * *}$ & 2.23 \\
Education & -17.56 & -0.14 \\
Accesswater & $-2285.73^{*}$ & -1.80 \\
Cholera & $8033.70^{* * *}$ & 5.05 \\
Dysentery & 5604.40 & 0.48 \\
Diarrhea & $3582.80^{*}$ & 1.88 \\
Typhoid fever & -7698.80 & -0.64 \\
Accesstoilet & $-5537.59 *$ & -1.76 \\
Accessrefuse & -1695.81 & -0.83 \\
State1 & $-4586.66^{* * *}$ & -3.40 \\
Constant & 1054.16 & 0.42 \\
Number of observations: & & \\
437 & & \\
Log likelihood & -3732.33 & \\
Pseudo R & 0.0065 & \\
Prob $>x$ & 0.0000 & \\
\hline
\end{tabular}

Note that $*$ indicates significant at $10 \%, * *$ significant at $5 \%$, $* * *$ significant at $1 \%$. Exchange rate was $\$ 160$ to $\$ 1$ at time of study

\section{CONCLUSIONS AND RECOMMENDATIONS}

Based on the results obtained, the economic cost of water-borne diseases was estimated at $\mathrm{N} 28,571.36$ ( $\$ 178.57$ ) per household per quarter and this was $35 \%$ of the average quarterly income of the study population. The factors that determined the economic burden of water-borne diseases in southwest, Nigeria were gender $(p<0.05)$, access to safe water $(p<0.1)$, cholera epidemic $(\mathrm{p}<0.01)$, diarrhea infection $(\mathrm{p}<0.1)$, access to improved sanitation $(\mathrm{p}<0.1)$ and the populace in Oyo State $(\mathrm{p}<0.01)$. The study concluded that households had low income generation owing to the fact that there was high cost incurred on time of the sick person and the caregiver. The study therefore recommends that rural households should consume quality water or water from improved sources (borehole or well water) so as to combat water-borne diseases. They should also seek medical attention when they fall ill. In the same vein, the three tiers of government (federal, state and local) should give more priority and sensitize rural households on water-borne diseases control programs in order to prevent economic losses which could have effect in terms of income money and food supply. 


\section{REFERENCES}

Adekoya, O. A. (2014). Analysis of Farm Households Poverty Status in Ogun State, Nigeria. Asian Economic and Financial Review, 4, 325-340.

Akinbode, S. O. (2010). Economic Burden of Diseases and Production Efficiency among Rice Farming Households in Ogun and Niger States, Nigeria. A PhD Thesis Submitted to the Department of Agricultural Economics and Farm Management, University of Agriculture, Abeokuta, 55-94.

Azizullah, A., Khattak, M. N. K., Ritcher, P., \& Harder, D. P. (2011). Water Pollution in Pakistan and its Impact on Public Health. A Review. International Journal on Environment, 37, 479-497.

Dzwairo, B., Hoko, Z., Love, D., \& Ghuza, E. 2006. Assessment of the Impacts of Pit Latrines on Groundwater Quality in Rural Areas. A Case Study from Marondera District, Zimbabwe. Journal of Physical Chemical Earth, 31, 779-788.

Edia, H. (2018, May 21). FarmCrowdy's Strides in Major Agricultural Producing State in Nigeria. FarmCrowdy. https://blog.farmcrowdy.com/agricultural-producing-states/

EpiAnalysis (2011, December 11). How to estimate the economic cost of a risk factor or disease. https://epianalysis.wordpress.com/2011/12/11/estimatecost/

Ibrahim, D. A., Okuneye, P. A., Dipeolu, A. O., \& Ayinde, I. A. (2010). Estimation of Cost of Treating Malaria among Arable Crop Farming Households in Niger State, Nigeria. Journal of Humanities, Social Sciences and Creative Arts, 5, 17-25

MacDonald, A. M. (2005). Groundwater and Rural Water Supply in Africa. Briefing Note of International Association of Hydrogeologists (IAH) Burdon Groundwater Network, Ghana, 4pp

Malik, A., Yasar, A., Tabinda, A. B., \& Abubakar, M. (2012). Water-Borne Diseases, Cost of Illness and Willingness to Pay for Diseases Interventions in Rural Communities of Developing Countries. Iranian Journal of Public Health, 41, 39-47.

Manggoel, W., Ajiji, I., Damar, W. K., Damiyal, D. M., Da'ar, J. W., \& Zaman, D. U. (2012). Agriculture as a Mitigating Factors to Unemployment in Nigeria. International Research Journal of Agricultural Sciences and Soil Science, 11, 465-468.

National Oceanic and Atmosphere Administration (NOAA) (2015). National Report on Climate. Federal Government of Nigeria, Abuja.

National Population Commission (NPC) (2006). Census Report. Federal Government of Nigeria, Abuja.

Odhiambo, G.O., Musuva, R.M., Atuncha, V.O., Mutete, E.T., Odiere. M. R., Onyango, R.O., Alaii, J.A., \& Mwinzi, P.N.M. (2014). Low Levels of Awareness Despite High revalence of Schistosomiasis among Communities in Nyalenda Informal Settlement, Kisumu City, Western Kenya. PLOS Neglected Tropical Diseases, 8, 1-8.

Omotesho, O. A., Adewumi, M. O., \& Ajayi, A. A. (1995). Labour Utilization in Peasant Agriculture. A Survey of four Local Government Areas in Kwara State, Nigeria. Centre Point Science Edition, 5, 77-99.

Pritchard, M., Mkandawire, T., \& O'Neill, J. G. (2008). Assessment of Groundwater Quality in Shallow Wells within the Southern Districts in Malawi. Journal of Physical Chemical Earth, 33, 812-823.

Rout, H. S., \& Nayak, N. C. (2007). Health and Health Economics: A Conceptual Framework. Health Economics in India, 13-29. 
Sauerborn, R., Adams, A., \& Hien, M. (1996). Household Strategies to Cope with the Economic Cost of Illness. Social Science Medicine, 43, 291-301

United Nations (UN). (2002). Facts about Water. Fact Sheet, Johannesburg Summit, Johannesburg, South Africa. Retrieved from http://www.un.org/jsummit/html/media_info/

United Nations. (2002). Facts about Water. Fact Sheet, Johannesburg Summit, South Africa http://www.un.org/jsummit/html/media info/

World Bank (1993). World Development Report: Investing in Health. World Development Indicators. Washington DC, World Bank Group. Oxford University Press, New York.

World Bank (2015, January 13). Global Economic Prospects to Improve in 2015, But Divergent Trends Pose Downside Risks Says WB. The Global Economic in Transition. A World Bank Group Flagship Report, Washington DC, 1-55.

World Health Organisation (WHO) and United Nations International Children's Emergency Fund (UNICEF). (2010). Joint Monitoring Report on: Progress on Sanitation and Drinking-Water - 2010 Update. World Health Organization, Geneva, 60

World Health Organisation (WHO). (2011, April 14). Strategies for Safe Management of Drinking-Water for Human Consumption: Report by the Secretariat. $64^{\text {th }}$ World Health Assembly. 